\title{
ISLAM DAN DEMOKRASI
}

Muhammad Taufik

Dosen Fakultas Syariah dan Hukum Institut Agama Islam Negeria (IAIN) Palu

muhammad_taufik@iainpalu.ac.id

Ardillah Abu

Dosen Fakultas Tarbiyah dan Ilmu Keguruan Institut Agama Islam Negeria (IAIN) Palu ardillah_abu@iainpalu.ac.id

\section{Abstrack}

Democracy is a word that is very popular among the people, almost all levels of society know and understand the meaning of democracy well. Democracy is part of a political system and government which, according to Abraham Lincoln, is defined as government by the people, to the people and for the people. Democracy is one concept that comes from the West. Democracy was only included in the treasury of Islamic thought in the mid-19th century because it was considered to have good values for life and not conflict with Islamic values. Therefore, they tried to find the equivalent of the word democracy in Islamic teachings, then the term shura was found. In the discourse and studies on the relationship between Islam and democracy, there are three opinions expressed by Islamic thinkers and figures about the relationship between Islam and democracy. First, there is no separation between Islam and democracy. Democracy is inherent or an integral part of Islam. Second, between Islam and democracy have conflicting relations. Third, in the relationship between Islam and democracy the third group does not accept it fully and does not reject it completely. This polemic of thought is then analyzed and studied further in accordance with the cultural context of Indonesian society.

Key words: Islam, demokrasi, indonesia

\section{Abstrak}

Demokrasi merupakan kata yang sangat populer dikalangan masyarakat, hampir seluruh lapisan masyarakat mengenal dan memahami dengan baik makna demokrasi. Demokrasi merupakan bagian dari sistem politik dan pemerintahan yang menurut Abraham Lincoln diartikan sebagai pemerintahan oleh rakyat, untuk rakyat dan kembali kepada rakyat. Demokrasi adalah salah satu konsep yang berasal dari Barat. Demokrasi baru masuk dalam khazanah pemikiran Islam pada paruh abad ke19 karena dianggap mempunyai nilai-nilai baik bagi kehidupan dan tidak bertentangan dengan nilai-nilai Islam. Oleh karena itu, mereka berusaha 
mencari padanan kata demokrasi dalam ajaran-ajaran Islam, lalu ditemukanlah istilah syura. Dalam wacana dan kajian-kajian tentang hubungan Islam dan demokrasi, terdapat tiga pendapat yang dikemukakan oleh pemikir dan tokoh-tokoh Islam tentang hubungan Islam dan demokrasi. Pertama, tidak ada pemisahan antara Islam dan demokrasi. Demokrasi inheren atau bagian integral dari Islam. Kedua, antara Islam dan demokrasi memiliki hubungan yang saling bertentangan. Ketiga, dalam hubungan Islam dan demokrasi kelompok ketiga tidak menerima sepenuhnya dan tidak menolak sepenuhnya. Polemik pemikiran ini kemudian dianalisis dan dikaji lebih lanjut yang disesuaikan dengan konteks budaya masyarakat Indonesia.

Key words: Islam, demokrasi, indonesia

\section{Pendahuluan}

Demokrasi merupakan kata yang sangat populer dikalangan masyarakat, hampir seluruh lapisan masyarakat mengenal dan memahami dengan baik makna demokrasi. Demokrasi sangat erat hubungannya dengan masyarakat. Demokrasi mempunyai arti penting bagi masyarakat, karena dengan demokrasi hak-hak untuk menyampaikan pendapat dan berpartisipasi aktif dalam pemerintahan negara mendapat jaminan dan perlindungan dari negara. Demokrasi adalah salah satu terminologi yang digunakan oleh beberapa negara termasuk negara yang berpenduduk muslim salah satunya adalah Indonesia.

Demokrasi merupakan bagian dari sistem politik dan pemerintahan yang dapat diartikan sebagai pemerintahan oleh rakyat, atau suatu doktrin yang mengakui bahwa rakyat dalam suatu sistem pemerintahan negara dipercaya memiliki kapasitas untuk memimpin masyarakat. Gagasan ini awal mulanya muncul pada abad kelima sebelum masehi di Yunani Kuno. Khususnya dikalangan penduduk Athena.

Demokrasi adalah salah satu konsep yang berasal dari Barat. Demokrasi baru masuk dalam khazanah pemikiran Islam pada paruh abad ke19 karena dianggap mempunyai nilai-nilai baik bagi kehidupan dan tidak bertentangan dengan nilai-nilai Islam. Pada permulaan abad ke 20 para pemikir Islam membicarakan dan mengkaji hubungan Islam dan demokrasi. Mereka menganggap bahwa demokrasi memiliki nilai positif. Oleh karena itu, mereka berusaha mencari padanan kata demokrasi dalam ajaran-ajaran Islam, lalu ditemukanlah istilah syura. Syura merupakan salah satu ajaran yang dibawa oleh Nabi Muhammad, kemudian dipraktekkan dalam Islam 
dalam kehidupan sehari-hari itu. Karena itu Islam diidentikkan dengan kata syura, sedangkan kalangan Barat lebih akrab dengan kata demokrasi.

Dalam kajian pemikiran politik Islam, persoalan Islam dan demokrasi adalah persoalan yang tidak pernah selesai dibahas dan selalu menjadi perdebatan yang tidak mempunyai titik temu dikalangan para pemikir dan para pakar ilmu politik. Mereka mengkaji secara serius permasalahan Islam dan demokrasi. Ada tiga alasan penting yang membuat masalah hubungan Islam dan demokrasi menjadi hal yang tidak pernah kunjung usai untuk dibahas dan selalu menjadi perhatian yang serius. Pertama, dilihat dari sumber atau rujukan pembahasan ini sangat banyak dan beragam. Islam mempunyai pengalaman historis yang cukup panjang selama lima belas abad yang dimulai dari praktek Nabi di Madinah hingga era sekarang, sehingga penulisan tentang Islam dan demokrasi menjadi sangat variatif dan banyak. Kedua, pembahasan tentang Islam dan demokrasi bersifat kompleks. Sehingga para peneliti mencoba menjelaskan permasalahan tersebut dengan pendekatan yang bersifat spesifik agar tidak terjebak dalam reduksionisme dan cenderung menyederhanakan masalah yang sebenarnya rumit dan kompleks. Ketiga, adanya pandangan yang bersifat ideologis dari berbagai kalangan atau kelompok tertentu dalam masyarakat Muslim, sehingga permasalahan Islam dan demokrasi dilihat dari kerangka ideologis tertentu dalam hal ini Islam, yang menjadikan masalah tersebut tidak pernah kunjung selesai untuk dibahas dan selalu menjadi permasalahan yang bersifat aktual dan menarik sepanjang masa. ${ }^{1}$

Dalam wacana dan kajian-kajian tentang hubungan Islam dan demokrasi, terdapat tiga pendapat yang dikemukakan oleh pemikir dan tokoh-tokoh Islam tentang hubungan Islam dan demokrasi. Pertama, tidak ada pemisahan antara Islam dan demokrasi. Demokrasi inheren atau bagian integral dari Islam. Karena itu, demokrasi tidak perlu dihindari dan menjadi urusan dari Islam. Demokrasi merupakan instrumen untuk mewujudkan dakwah Islamiyah, sehingga masuk dalam proses politik khususnya dalam proses demokrasi menjadi suatu keharusan dalam Islam. Hubungan Islam dan demokrasi semacam ini disebut hubungan integralistik atau hubungan yang terpadu, yang tidak dapat dipisahkan satu sama lain. Adapaun

${ }^{1}$ Idris Thaha, "Demokrasi Religius: Pemikiran Politik. Nurkholish Madjid dan M. Amin Rais, (Jakarta: Teraju, 2005), h. 7. 
tokoh-tokoh yang masuk dalam kategori ini diantaranya adalah Muhammad Abduh, Rasyid Ridha, Yusuf al-Qardhawi, Fahmi Huwaidi, Muhammad Husain Haikal, Sadek Jawad Sulaiman, Abid al-Jabiri, Fazlur Rahman, Abdurahman Wahid, Amin Rais, Syafi'i Ma'arif, Nurkholis Madjid, Azyumardi Azra dan lain-lain. Kedua, antara Islam dan demokrasi memiliki hubungan yang saling bertentangan. Hubungan Islam dan demokrasi dipandang saling berhadapan, berlawanan dan saling bermusuhan. Islam dan demokasi tidak memiliki hubungan sama sekali. Keduanya saling terpisah dan tidak saling terkait. Dalam Islam tidak dikenal yang namanya demokrasi. Demokrasi merupakan produk Barat dan tidak bersumber dari Islam, demokrasi bertentangan dengan ajaran Islam. Hubungan ini sering disebut dengan hubungan antagonistik atau hubungan yang saling bertetentangan. Tokoh-tokoh yang mengusung dan mendukung pemikiran ini adalah Taufiq Muhammad Asy-Syawi, Syaikh Fadlullah Nuri, Sayyid Qutb, Ali Benhadj, Hasan at-Thurabi, Abdul Qadim Zallum, Abu Bakar Baasyir dan lain-lain. Ketiga, dalam hubungan Islam dan demokrasi kelompok ketiga tidak menerima sepenuhnya dan tidak menolak sepenuhnya. Artinya mereka mengakui antara Islam dan demokrasi memiliki kesamaan dan perbedaan. Dalam demokrasi dikenal beberapa nilai etis yang memiliki kesamaan dengan Islam, seperti kebebasan (al-hurriyah), persamaan (al-Musawwa), toleransi (at-tasammub), keadilan (aladalab) dan lain-lain. Dan perbedaan antara Islam dan demokrasi adalah dari sisi sumbernya. Demokrasi dapat diterima dan diberlakuakan dalam suatu negara dengan beberapa catatan penting yang tidak bisa diabaikan. Demokrasi harus disintesiskan dengan Islam. Hubungan semacam ini disebut hubungan simbiosis-mutualisme atau hubungan yang saling menguntungkan dan memberi manfaat sehingga tidak dapat dipisahkan satu sama lain. Adapun tokoh-tokoh yang mendukung pemikiran ini ialah Abu Al-A'la al-Maududi, Muhammad Iqbal, Abdul Karim Soroush, Imam Khomeini, Muhammad Dhiyauddin Ar-Rais dan lain-lain.

Dalam menyikapi perbedaan pendapat dikalangan para pemikir dan tokohtokoh Islam ini, selaku penulis pertanyaan kritis yang muncul adalah mengapa sebagian kelompok Islam menentang dan menolak demokrasi? Apakah demokrasi sangat bertentangan dengan Islam karena ia berasal dari Barat? Apakah Islam tidak boleh mengadopsi sistem demokrasi? Beberapa petanyaan ini menjadi fokus dalam pembahasan selanjutnya. 


\section{Pembahasan}

\section{Kelompok Yang Menentang Hubungan Islam dan Demokrasi}

Salah satu tokoh yang menentang demokrasi adalah Syaikh Fadlullah Nuri, ia mengatakan gagasan kunci demokrasi yaitu persamaan semua warga negara ini adalah suatu imposibble atau tidak mungkin dalam Islam. Perbedaan merupakan sesuatu yang tidak dapat dihindari seperti adanya orang beriman dan tidak beriman, orang kaya dan orang miskin, ahli hukum Islam atau fakih dan pengikutnya. Selain itu ia juga merupakan legislasi yang dibuat oleh manusia. Dalam Islam tidak ada sesuatupun yang berhak mengatur hukum. Paham konstitusional dalam demokrasi sangat bertentangan dengan Islam. Islam adalah agama yang sempurna yang mengatur segala aspek kehidupan. Lebih jauh Sayyid Quthub salah seorang anggota ikhwanul muslimin Mesir sangat menentang gagasan kedaulata rakyat atau yang dikenal dengan istilah demokrasi. Baginya hal itu adalah penentangan dan pelanggaran terhadap kekuasaan Tuhan dan merupakan bentuk tirani dari sebagian manusia terhadap yang lainnya. Mengakui kekuasaan Tuhan berarti melakukan penetangan secara menyeluruh terhadap kekuasaan manusia dalam seluruh pengertian, bentuk dan sistem. Syariat atau aturan Tuhan merupakan satu sistem hukum dan sistem moral yang sudah lengkap. Sehingga tidak perlu ada penambahan lagi dengan legislasi manusia. ${ }^{2}$

Salah seorang pemimpin FIS (Front Islamique du Salut) asal Aljazair Ali

Benhadj berulang-ulang mengatakan bahwa demokrasi adalah konsep Yudeo-Kristen yang harus diganti dengan prinsip-prinsip pemerintahan yang sejalan dengan Islam. Menurut Ali Benhadj dalam pandangan pemikir Barat bahwa demokrasi adalah sistem yang cacat. Secara khusus konsep tentang suara mayoritas dalam sistem demokrasi mudah ditolak karena isu-isu yang terkait dengan hak dan keadilan tidak dapat dikuantifikasi. Semakin banyak jumlah suara mayoritas tidak dengan sendirinya

${ }^{2}$ Sukron Kamil, "Pemikran Politik. Islam Tematik: Agama dan Negara, Demokrasi Civil Society, Syariah, Ham, Fundamentalime Anti Korupsi”, ( Jakarta: Kencana, 2013), h. 94-95. 
memperbaiki moralitas masyarakat. Demokrasi hanyalah merupakan alat Barat yang akan menghasilkan pemerintahan yang pro terhadap Barat. ${ }^{3}$

\section{Kelompok Yang Mengakui Adanya Kesamaan dan Perbedaan Antara Islam dan Demokrasi}

Sebagaimana pada sebagian pemikir kelompok pertama, kelompok kedua menyetujui adanya prinsip-prinsip demokrasi dalam Islam tetapi dilain pihak mengakui adanya perbedaan antara keduanya. Di antara pemikir Islam yang mengakui adanya kesamaan dan perbedaan antara Islam dan demokrasi adalah Abul 'Ala alMaududi dari Pakistan. Menurut al-Maududi ada kemiripan demokrasi dan Islam. Kesamaan wawasan itu seperti keadilan (Qs. 42:15), persamaan (Qs. 49: 13), akuntabilitas dalam pemerintahan (Qs. 4: 58), hak-hak oposisi (Qs. 33: 70, dan 4: 35), tujuan negara (22:4), dan musyawarah dalam (Qs. 2: 233, 3: 159, dan 42: 38). Akan tetapi, letak pebedaannya sebabaimana dalam sistem demokrasi yang berasal dari Barat rakyat memiliki hak-hak kedaulatan mutlak, maka dalam demokrasi Islam atau sistem syura kekuasaan dibatasi oleh hukum-hukum Ilahi. Suatu negara didirikan atas prinsip-prinsip kedaulatan Tuhan dan tidak menerima legislasi atau pembuatan hukum yang berasal dari manusia. Sistem Islam menempuh cara moderat yaitu sistem pemerintahan Theo-Demokrasi. Suatu sistem pemerintahan demokrasi ilahi dimana kedaulatan rakyat dibatasi oleh kedaulatan Tuhan melalui hukum-hukumnya. Suatu negara tidak dapat membuat aturan undang-undang yang betentangan dengan hukum Tuhan yang bersumber dalam Al-Qur'an dan Hadits, sekalipun merupakan kesepakatan dari rakyat secara umum. Kasus lolosnya RUU tentang minuman keras yang berlaku di Amerika sebagai negara pioner sistem demokrasi, tidak akan terjadi dan bakal berlaku dalam sistem pemerintahan Islam. Namun hal ini tidak berarti melakukan pemasungan terhadap potensi rasional manusia dan tidak memberikan ruang untuk pembuatan suatu aturan undang-undang yang bersumber dari manusia. Semua persoalan administrasi dan masalah yang tidak memiliki penjelasan yang

3Sukron Kamil "Islam dan Demokrasi: Telaah Konseptual dan Historis", (Jakarta: Gaya Media Pratama, 2002), h. 48. 
gamblang dalam syariah ditetapkan berdasarkan konsensus yang berlaku di antara kaum muslimin yang memiliki kualifikasi. ${ }^{4}$

Salah seorang pemikir yang mempunyai kemiripan cara pandang dengan Abul A'la Al-Maududi tentang hubungan Islam dan demokrasi adalah Dr. Dhiya'uddin ArRais, salah seorang dosen ilmu sejarah asal Universitas Darul Ulum, Mesir. Dhiya'uddin Ar-Rais sebagaimana yang dikutip dalam bukunya Fahmi Huwaidi memgatakan bahwa ada beberapa sisi kesamaan yang mempertemukan antara Islam dan demokrasi, selain itu juga memiliki sisi perbedaan yang banyak. ${ }^{5}$

Menurut Dhiya'uddin Ar-Rais terdapat beberapa sisi kesamaan antara Islam dan demokrasi. Pertama, jika yang dimaksud dengan demokrasi sebagaimana yang dikemukakan oeh Abraham Lincoln adalah pemerintahan yang berasal dari rakyat, oleh rakyat dan untuk rakyat, pengertian ini juga terdapat dalam sistem pemerintahan Islam, dengan pengecualian bahwa rakyat harus memahami Islam secara komprehensif. Kedua, jika yang dimaksud dengan demokrasi adalah adanya hak-hak dasar politik atau sosial tertentu, seperti asas persamaan di hadapan undang-undang, kebebasan berpikir dan berkeyakinan, pemerataan kesejahteraan sosial dan lain sebagainya, atau memberikan hak-hak tertentu, seperti hak untuk hidup, bebas, dan mendapatkan pekerjaan, serta hak-hak lainnya. hak-hak tersebut semuanya dijamin dalam Islam. Namun, pandangan Islam tentang hak-hak tersebut, secara alami terkadang bisa beragam: terkadang Islam memandang hak-hak tersebut sebagai hakhak Allah dan terkadang menganggapnya sebagai hak-hak bersama antara Allah dan hamba-hambanya. Bahkan, Islam menetapkan bahwa hak-hak itu merupakan dasar dari segala sesuatu, atau sebagai undang-undang yang diletakkan Allah karena ada eksistensi atau fitrah manusia. Ketiga, apabila demokrasi dipahami sebagai pemisahan kekuasan dalam lembaga-lembaga pemerintahan, seperti eksekutif, legislatif dan yudikatif. Ini juga ada dalam sistem Islam. Dalam demokrasi kekuasaan legislatif sebagai reprentasi dari rakyat, terpisah dari kekuasaan eksekutif yang dikepalai oleh seorang Imam atau presiden. Dalam Islam lembaga syura atau pembuat undangundang membuat aturan undang-undang berdasarkan Al-Qur'an dan Hadits atau ijma

${ }^{4}$ Ibid., h. 49-50.

${ }^{5}$ Dhiya'uddin Ar-Rais dalam Fahmi Huwaidi "Demokrasi Oposisi dan Masyarakat Madani", penerjemah Muhammad Abdul Ghoffar, (Bandung: Mizan, 1996), h. 196-199. 
dan ijtihad. Dengan demikian, pembuatan undang-undang atau hukum tersebut terpisah dari imam atau pemimpin dalam suatu negara.

Sedangkan sisi perbedaan antara Islam dan demokrasi, Dhiya'uddin Ar-Rais menerangkan dalam tiga hal. Pertama, kata "bangsa" atau "umat" yang dimaksud dalam demokrasi modern yang populer dikalangan Barat adalah yang dibatasi oleh letak geografis, dimana individu-individu didalamya terikat oleh, ikatan darah, etnis, agama, bahasa, dan kultur yang berkembang dalam bangsa tersebut. Dengan kata lain, demokrasi selalu diiringi dengan pemikiran nasionalisme, atau rasialisme yang digiring oleh tendensi fanatisme. Sementara dalam Islam kata "umat" tidak harus terikat oleh suatu tempat, darah atau bahasa. Ikatan-ikatan hanyalah merupakan rekayasa semata, atau hanya merupakan masalah sekunder. Tetapi ikatan sebenarnya yang mengikat umat hanya satu yaitu akidah. Atau yang terletak pada pemikiran dan perasaan. Setiap orang mengikuti Islam, dari jenis warna kulit yang berbeda, bahasa yang berbeda, dan negara apapun maka ia termasuk dalam anggota persaudaraan Islam. Dengan demikian, pandangan Islam sangatlah manusiawi dan bersifat internasional, hal ini amatlah penting dalam rangka mewujudkan kemaslahan manusia secara umum.

Kedua, tujuan-tujuan dari demokrasi modern Barat atau segala bentuk demokrasi yang pernah ada dan dipraktekkan dalam kurun waktu tertentu, hanyalah mempunyai tujuan-tujuan yang bersifat material dan sebatas pada kehidupan duniawi. Jadi, tujuan demokrasi hanya sebatas untuk merealisasikan kesejahteraan umat atau bangsa dalam pemenuhan kebutuhan dunia yang berupa misalnya pengembangan kekayaan, peningkatan gaji, dan sebagainya. Hal ini, berbeda dengan tujuan-tujuan sistem Islam atau demokrasi Islam, selain mencakup pemenuhan terhadap tujuantujuan yang bersifat duniawi atau material, dengan memberikan semua kebutuhan yang dikehendaki di dunia, dan menjauhkan fanatisme rasial, demokrasi Islam juga mempunyai tujuan-tujuan yang bersifat spiritual. Bahkan tujuan-tujuan spiritual lebih utama dan sangat fundamental.

Ketiga, kekuasaan umat atau rakyat dalam demokrasi Barat modern bersifat mutlak. Jadi, rakyat adalah pemegang kekuasaan tertinggi. Rakyat atau wakil-wakil yang dipilih olehnya yang membuat dan membatalkan undang-undang dan hukum. Dan segala keputusan yang dikeluarkan oleh dewan perwakilan ini, menjadi ketentuan yang harus dijalankan dan ditaati, walaupun ketentuan tersebut bertetangan dengan 
norma-norma susila, atau bertentangan dengan kemaslahatan manusia secara umum. Misalnya, jika demokasi modern mengumumkan perang walaupun hanya untuk kepentingan suatu bangsa untuk menguasai segala sumber daya dan minyak dalam suatu negara yang mengasilkan penderitaan pertumpahan darah, pembantaian dan penderitaan umat manusia. Tetapi dalam Islam, kekuasaan rakyat tidak bersifat mutlak, melainkan terikat dengan ketentuan-ketentuan syariat agama berdastkan AlQur'an dan dan Hadits yang dipeluk oleh setiap individu-individu dari rakyat tersebut. Jadi, rakyat dibatasi oleh norma-norma susila dan terkait dengan prinsipprinsipnya, dan agama telah memberikan kewajiban kepada umat serta membebaninya dengan berbagai tanggung jawab.

\section{Kelompok yang Mengakui Kesamaan antara Islam dan Demokrasi}

Berbeda dengan dua kelompok sebelumnya, kelompok ketiga memandang bahwa Islam mempunyai persamaan dengan demokrasi. Islam dalam dirinya sudah demokratis dan menerima sepenuhnya demokrasi sebagai sesuatu yang universal. Fahmi Huwaidi adalah salah satu dari sekian banyak pemikir Islam melakukan sintesa yang viable anatara Islam dan demokrasi. Ada beberapa alasan yang dikemukan oleh Fahmi Huwaidi terkait dengan persoalan tersebut. Pertama, beberapa Hadits menunjukkan bahwa Islam menghendaki pemerintahan yang disetujui oleh rakyat. Dalam Hadits riwayat Muslim dari 'Auf bin Malik disebutkan, "Sebaik-baiknya imamimam (penguasa) kalian adalah orang-orang yang kalian sukai dan merekapun menyukai kalian, yang kalian doakan dan merekapun mendoakan kalian. Sementara seburuk-buruknya imam kalian adalah yang kalian benci dan merekapun membeci kalian, yang kalian laknat dan merekapun melaknat kalian”. Kedua, penolakan Islam terhadap kediktatoran. Banyak ayat Al-Qur'an menunjukkan hal ini, QS. 2:258 misalnya mengecam namrudz yang mengaku bahwa dirinya sebagai Tuhan dan berlaku sewenang-wenang terhadap rakyatnya dengan membunuh orang yang tidak bersalah. Ketiga, dalam Islam pemilu merupakan kesaksian rakyat dewasa bagi kelayakan seorang kandidat dan mereka tentu saja seperti yang diperintahkan Al-Qur'an (QS. 2:282-283), mesti tidak menyembunyikan persaksiannya, mesti bersikap adil dan jujur serta tidak menjadi saksi-saksi palsu (QS.22:30 dan QS 65:2). Keempat, demokrasi merupakan sebuah upaya untuk mengembalikan sistem kehalifahan Khulafa Rasyidin yang memberikan hak kebebasan pada rakyat. Kelima, negara Islam adalah negara keadilan dan 
persamaan manusia di depan hukum. Keenam, seperti dirumuskan oleh teoritisiteoritisi Islam semisal Al-Mawardi Imamah atau kepemimpinan politik adalah kontrak sosial yang riil yang karenanya jika seorang penguasa tidak mau menerima teguran boleh diturunkan dari kekuasaannya dan diganti dengan yang lain. ${ }^{6}$

Selain Fahmi Huwaidi, terkait persoalan upaya pengintegrasian antara Islam dgan demokrasi terdapat pemikir yang menerima sepenuhnya dalam pengertian Barat tenpa penyaringan sama sekali. Mereka menerima secara sepenuhnya demokrasi liberal dalam pengertian Barat. Seperti Muhammad Said Al-Ashmawy dan Faraj Fada yang menolak secara tegas pemerintahan Tuhan (Theokrasi). Seperti model kelompok pertama atau model kelompok kedua, dengan melihatnya bahwa hal itu keliru secara Islam dan sebagai cara untuk menutupi kecenderungan totalternya dengan konsep ishmah (kesucian dari dosa). Dan apa yang disebut ideologi Islam bukanlah konsep otentik Islam. Politik dalm Islam bukanlah doktrin yang sudah pasti dan definitif menurut Al-Ashmawy. Politik bukanlah persoalan ketuhanan atau kemaksuman., tetapi kemanusiaan dan demokrasi adalah bagian dari perbaikan dan progresifitas sistem politik yang tak terelakkan untuk diadopsi Islam. ${ }^{7}$

\section{Tanggapan Terhadap Ketiga Kelompok}

Menyikapi perbedaan pemahaman dari ketiga kelompok ini, selaku penulis saya tidak menyetujui pendapat-pendapat kelompok pertama dan kedua, walaupun tidak membenarkan sepenuhnya kelompok ketiga dengan beberapa alasan berikut. Pertama, pemikiran kelompok pertama yang menentang demokrasi dilatari oleh kesalahpahaman mereka terhadap QS. 16:89 "Dan kami turunkan kepadamu al-Kitab untuk. menjelaskan segala sesuatu dan petunjuk serta rabmat dan kabar gembira bagi orang-orang yang berserah diri”. Ayat ini dipahami oleh mereka bahwa Al-Qur'an mengandung penjelasan terhadap segala obyek kehidupan, tidak dipahami mengandung penjelasan terhadap segala aspek panduan moral atau etika. Diasmping itu pemahaman mereka terhadap Al-Qur'an sangat sempit dan tidak kontekstual, mereka terjebak dalam pandangan-pandangan klasik yang memahami dan menafsirkan ayat-ayat hanya berdasarkan makna tekstualnya dan tidak menafsirkan teks Al-Qur'an dengan melihat budaya dan konteks sebuah masyarakat. Kedua, alasan penolakan kelompok kedua 
terhadap hal-hal yang dari Barat hanyalah bersifat emosional dan psikologis sebagai respon dari penjajahan dunia Barat terhadap dunia Islam. Padahal tidak semua hal yang dari Barat itu harus ditolak. Selama hal-hal yang berasal dari Barat itu bersifat positif dan tidak bertentangan dengan prinsip-prinsip Islam termasuk sistem demokrasi mengapa kita tidak mengambilnya.

Pemikiran kelompok yang menentang demokrasi sebenarnya didasari oleh satu konsep bahwa Islam adalah agama yang sempurna sehingga tidak perlu lagi ada penambahan terhadapnya. Demokrasi mengendaki kedaulatan ditangan rakyat sedangkan Islam kedaulatan mutlak ada ditangan Tuhan. Demokrasi adalah produk Barat yang merupakan hasil dari pemikiran manusia. Menurut penulis kelompok yang menetang demokrasi ini sebenarnya salah paham terhadap Islam dan demokrasi itu sendiri. Kesempurnaan Islam adalah karena ia merupakan aspek panduan moral dalam bertingkah laku. Tetapi dalam menentukan sistem apa yang cocok dalam suatu sistem pemerintahan, Rasulullah tidak pernah menentukan satu sistem yang baku yang dapat digunakan secara kontinyu dalam pemerintahan Islam. Hal ini diserahkan kepada ijtihad manusia. Kedaulatan rakyat tidaklah bertentangan dengan kedaulatan manusia. Sebagai khalifah Allah dimuka bumi, manusia merupakan pelaksana dan penafsir apa yang berasal dari Tuhan. Manusia berhak untuk membuat suatu legislasi yang tidak ada aturannya baik dalam Al-Qur'an dan Hadits Nabi, dan manusia memiliki wewenang untuk menafsirkan Al-Qur'an dan Hadits sesuai dengan konteks suatu masyarakat kemudian membuat suatu aturan hukum sebagaimana yang dilakukan oleh khalifah-khalifah sebelunya, khususnya Umar bin Khattab. Demokrasi walaupun ia bersumber dari Barat dan merupakan hasil pemikiran manusia, selama nilai yang dikandungnya tidak bertentangan dengan Islam mengapa kita tidak mengambilnya, karena pada intinya demokrasi tidak sepenuhnya bertentangan dengan Islam. Sehingga demokrasi dapat diberlakukan dalam pemerintahan atau negara yang mayoritas berpenduduk Muslim.

Selanjutnya, penulis sependapat dengan ketiga yang mengakui bahwa demokrasi dan Islam adalah suatu hal yang terpadu dan tidak boleh dipisahkan satu sama lain antara Islam dan demokrasi tidak perlu dipertentangkan. Islam dan demokrasi bersifat integral. Alasannya ialah: pertama, pemikiran kelompok yang menyelaraskan hubungan Islam dan demokrasi lebih bersifat moderat dan inklusif. 
Mereka mencoba melakukan sintesis antara Islam dan demokrasi. Pemikiran ini lebih dapat diterima oleh kalangan Muslim secara mayoritas. Kedua, seacara historis kehadiran Islam adalah sebagai bentuk protes terhadap ketidakadilan dan tirani yang dilakukan penguasa jahiliyah pada saat itu, dan berusaha membebaskan manusia dari belenggu ketidakbebasan terutama dalam beragama dan berkeyakinan. Sama halnya dengan perjalanan demokrasi di Barat, kehadiran demokrasi adalah sebagai bentuk protes terhadap kekuasaan tirani kaum aristokrat dan raja, dan otoritas gereja yang bersifat sewenang-wenang terhadap rakyat jelata. Sehingga antara demokrasi dan Islam secara historis mempunyai semangat yang sama dalam hal penentangan terhadap kekuasaan tirani dan segala bentuk ketidakadilan.

Menurut Muhammad Abid al-Jabiri, demokrasi tidak hanya menjadi produk historis Barat, tetapi ia sangat relevan untuk diterapkan dengan kondisi sekarang ini, bahkan merupakan salah satu keniscayaan zaman kita, karena demokrasi sangat menjunjung tinggi hak-hak rakyat dalam sebuah negara, yaitu hak untuk memilih, mengawasi dan mencopot penguasa, hak kebebasan berbicara, berkumpul, membuat partai dan organisasi, hak pendidikan dan pekerjaan, hak persamaan yang diiringi oleh keseimbangan kesempatan politik dan ekonomi. ${ }^{8}$ Prinsip-prinsip demokrasi yang dikemukakan oleh Abid al-Jabiri ini, sangat sejalan dengan ajaran Islam.

Ketiga, dalam Islam dikenal prinsip-prinsip seperti kebebasan (al-burriyab), kesamaan (al-musawwa), toleransi (at-tasammub), keadilan (al-adalab), musyawarah (syura), dan kebenaran (as-shidq), ini sejalan dengan prinsip-prinsip demokrasi. Dalam negara demokratis, prinip-prinsip tersebut menjadi hal yang sangat dipertahankan dan diperjuangkan untuk dapat diterapkan dalam negara tersebut.

Walaupun penulis sejalan dengan kelompok pertama, tetapi ada beberapa catatan penting terhadap proses penerapan demokrasi khususnya di Indonesia. Pertama, demokrasi seharusnya berdiri diatas kepentingan mayoritas rakyat yang menjadi tujuan inti dari demokrasi, hasil dari keputusan mayoritas dalam parlemen dan penyelengaraan pemerintahan seharusnya menguntungkan dan mementingkan kepentingan mayoritas rakyat, bukan berdiri di atas kepentingan elit tertentu, atau kepentingan kelompok tertentu. Kedua, pelaksanaan demokrasi seharusnya 
disesuaikan dengan konteks dan budaya suatu masyarakat. Jika di Barat pelaksanaan demokrasi bersifat sekuler yaitu memisahakan anatara agama dan negara, maka dalam dunia Islam pelaksanaan demokrasi seharusnya tidak memisahkan antara agama dan negara. Ketiga, praktek demokrasi khususnya dalam proses pemilihan eksekutif maupun legislatif, aksi masa, pelaksanaan sidang paripurna oleh anggota DPR, dan lain-lain seharusnya tetap berjalan dalam koridor dan batas-batas etika, dan tidak mencerminkan aksi-aksi yang frontal dan reaksioner.

\section{Kesimpulan}

Kelompok yang menentang hubungan Islam dan demokrasi pada dasarnya berpandangan bahwa Islam adalah agama yang sempurna yang mengatur segala aspek kehidupan. Dalam Islam kedaulatan mutlak ada pada Tuhan, sedangkan dalam demokrasi kedaulatan mutlak berada pada rakyat. Islam bersumber dari Tuhan dan demokasi bersumber dari Barat yamg merupakan hasil pemikiran manusia. Pemikiran tokoh-tokoh Islam yang berpandangan demikian menurut penulis adalah suatu kesalahpahaman. Kesempurnaan Islam karena ia menjadi panduan moral dalam bertingkahlaku, tetapi dalam hal sistem pemerintahan yang diterapkan dalam suatu negara, tidak ada sistem yang baku dan bersifat final yang harus diikuti berdasarkan ketentuan Rasulullah dan khalifah penerusnya. Antara kedaulatan Tuhan dan kedaulatan rakyat semestinya tidak tidak perlu dipertentangkan, rakyat dalam hal ini manusia adalah khalifah Tuhan dimuka bumi yang merupakan pelaksana dan penafsir pesan-pesan yang disampaikan Tuhan. Dan demokrasi walaupun bersumber dari Barat, selama tidak bertentangan dengan konsep Islam dan mempunyai manfaat yang cukup besar, kita seharusnya mengambilnya dan menerapkan dalam kehidupan bernegara.

Hubungan Islam dan demokrasi yang sejalan dan tidak bertentangan sebagaimana yang dikemukan oleh tokoh-tokoh pendukungnya hal ini sejalan dengan pemikiran penulis karena dengan berbagai alasan diantaranya dua hal, yaitu: pertama, secara historis kehadiran Islam dan demokrasi sama-sama sebagai bentuk penentangan terhadap kekuasaan tirani dan ketidakadilan yang dilakukan oleh penguasa. Kedua, secara prinsip dan nilai, antara Islam dan demokrasi memiliki sisi perbedaan dan kesamaan, diantara prinsip dan nilai-nilai Islam yang sejalan dengan 
demokrasi ialah: kebebasan (al-burriyab), kesamaan (al-musawwa), toleransi (attasammub), keadilan (al-adalah), musyawarah (syura), dan kebenaran (as-shidq).

Walaupun penulis sependapat dengan kelompok yang mengakui hubungan keterkaitan antara Islam dan demokrasi, tetapi ada beberapa catatan penting dalam sistem demokrasi. Pertama, pelaksanaan demokrasi seharusnya berdiri di atas kepentingan rakyat mayorits, dan mengutamakan apa yang menjadi kebutuhan dan hak-hak rakyat, bukan berdiri di atas kepentingan kaum elit dan golongan tertentu. Kedua, pelaksanaan demokrasi seharusnya disesuaikan dengan konteks dan budaya masyarakat setempat. Ketiga, penerapan demokrasi seharusnya berada dalam koridor dan bata-batas etika.

\section{Daftar Pustaka}

Abid al-Jabiri, Muhammad, Syura: Tradisi-Partikularitas-Universalitas, Yogyakarta: LkiS, 2003.

Huwaidi, Fahmi 'Demokrasi Oposisi dan Masyarakat Madani”, Bandung: Mizan, 1996

Kamil, Sukron, "Pemikran Politik Islam Tematik: Agama dan Negara, Demokrasi Civil Society, Syariah, Ham, Fundamentalime Anti Korupsi”, Jakarta: Kencana, 2013.

Kamil, Sukron "Islam dan Demokrasi: Telaah Konseptual dan Historis", Jakarta: Gaya Media Pratama, 2002.

Thaha, Idris, "Demokrasi Religius: Pemikiran Politik. Nurkholish Madjid dan M. Amin Rais, Jakarta: Teraju, 2005. 